\title{
Is It Harmful? A Thomistic Perspective on Risk Science in Social Welfare
}

\author{
Saša Horvat ${ }^{1}$ (D) $\cdot$ Piotr Roszak ${ }^{2}$ (D) $\cdot$ Brian J. Taylor $^{3}$ (D)
}

Accepted: 28 October 2021 / Published online: 8 November 2021

(C) The Author(s), under exclusive licence to Springer Science+Business Media, LLC, part of Springer Nature 2021

\begin{abstract}
Probabilistic information is used increasingly, from medical research to weather forecasting. The relationship between probability and causality requires an acceptable philosophical account. Social work, which contributes to healthy wellbeing, increasingly uses language of probabilistic causal relationships between harms and subsequent limitations to healthy functioning. This paper explores causal understandings of probabilistic knowledge using concepts of the theologian, Thomas Aquinas. Social welfare terminology regarding risk (such as factors that are 'causative of' child abuse) is explored using epistemological concepts from scholastic philosophy. Aquinas' anthropological concepts related to modern 'risk science' and his concepts of rationality, harm and prudence are applied to contemporary social welfare.
\end{abstract}

Keywords Epistemology $\cdot$ Probability $\cdot$ Risk $\cdot$ Scholastic philosophy $\cdot$ Social work

Saša Horvat

sasa.horvat@medri.uniri.hr

Piotr Roszak

piotrroszak@umk.pl

Brian J. Taylor

bj.taylor@ulster.ac.uk

1 Department of Social Sciences and Medical Humanities, Faculty of Medicine, University of Rijeka, Braće Branchetta 20, 51000 Rijeka, Croatia

2 Department of Christian Philosophy, Faculty of Theology, Nicolaus Copernicus University, Toruń, Poland

3 School of Applied Social and Policy Studies, Ulster University, Belfast, Northern Ireland 


\section{Introduction}

The modern world increasingly uses probabilistic information, from trivial situations such as gambling to life-changing contexts such as medical research and daily contexts such as weather forecasting. This probabilistic information is becoming increasingly accurate (such as in weather forecasting) and increasingly important for the ways in which societies are influenced and led (such as in the impact of social media). The relationship between the statistical information about probabilities and causality is one for which an acceptable philosophical account is required. An aspect of increasing interest is in relation to social welfare, where we speak of such things as childhood abuse 'causing' mental health problems in adulthood, although we do not mean that every abused child has subsequent mental health problems nor that every person with mental health problems has been abused in childhood. The language of probabilistic causal relationships between harms and subsequent limitations in personal and societal functioning is becoming increasingly common. In this paper, we explore causal descriptions of such probabilistic knowledge regarding social welfare aspects of health, using the concepts of scholastic philosophy derived from the work of the theologian, Thomas Aquinas.

The World Health Organization (WHO) defines health as 'a state of complete physical, mental and social wellbeing and not merely the absence of disease or infirmity' (WHO, 1948, p. 1). The WHO links health with wellbeing, emphasizing the importance of social factors for health. By the concept of "social wellbeing", we could include: "adequate and well-functioning social relationships, adequate social support, little or no social strain, some social participation, social inclusion..." (Waite, 2018, p. 100). In the context of the importance of social wellbeing for health of individuals and populations, this article focuses on a contemporary issue at the interface between religion and health: probabilistic understandings of harm to individuals and families.

\section{Probability in Everyday Decision-Making and Scientific Knowledge}

If you roll the dice what is the probability that it will fall to number five? Or number three? What is the probability that you will be doing your current job until retirement? What is the risk of getting infected with the COVID-19 virus indoors with ten people? When we talk about probabilities, we may first think of gambling, weather forecasting or certain medical theories. Under the concept of risk or probability, Rosenberg and McIntyre (2020) posit several perspectives: the subjective degree of belief that some proposition is true, meaning that probabilities are not real events in the world but purely subjective states of scientists (Bayesianism); the long-run relative frequency that something will happen under certain circumstances like in weather forecasting probabilities; or a sheer possibility that some ('unique') event will happen, for example in quantum mechanics or some other event, such as lightning strikes, where the probability is currently regarded as incalculable. Theorists usually distinguish between two distinct 
senses of probability: subjective (the likelihoods in our beliefs about future events even where this is not calculable) and objective (the probabilities of future events where these are, at least in principle, calculable) (Daston, 1994). The first emphasizes the judgment in the head, bringing to the fore the account of how likely an individual believes some rare event may occur-e.g., a meteor striking the earth in a particular locality (Savage, 1954; Finetti, 1975/2017). The term 'likelihood' is usually used for this meaning. The second meaning puts aside subjective feelings and inclinations to focus on the objective 'probability'. This is based on the mathematical analysis of concrete data about past similar events to calculate the probability distribution for some event occurring again. The probability of this event is "... one more factual issue on which different scientific theories can disagree" (Eagle, 2016, p. 417). These subjective and objective probability can be in fruitful relation as in weather forecasts, where preceding rainfall statistics producing a probability distribution have an important role, although the individual meteorologist or a farmer may also have a personal estimate of rain tomorrow based on 'intuitive' or 'heuristic' factors that are not yet part of a mathematical model (Gigerenzer et al., 1989; Taylor, 2017a).

Historically, the beginnings of the theory of probability are often attributed to the analysis of gambling by Gerolamo Cardano in the sixteenth century. The theory was then developed substantially by Pierre de Fermat and Blaise Pascal in the seventeenth century. From gambling, probability theory expanded into the field of law, data analysis, insurance, and then into sociology, physics and psychology in the nineteenth century, and then into areas such as agriculture, medicine, sports and many others in the twentieth century (Gigerenzer et al., 1989). In the nineteenth century, Pierre Laplace created the classical interpretation of the theory of probability, with a notable contribution by Andrey Nikolaevich Kolmogorov.

Probability calculations regarding certain risks have been applied to a vast number of areas in our lives. Nowadays large data systems based on the mathematical and logical principles of probability collect and use vast amounts of information from real-life events. Probabilities can be viewed as a way to express causal relations or as grounds for causal explanations (Rosenberg \& McIntyre, 2020); we discuss this further below in relation to health and social welfare. Nevertheless, the relationship between statistical correlation and causation presents philosophical dilemmas.

Those with expertise in a field, as well as lay people in everyday situations, use the results of probability theory to inform their decisions about risks. "Sometimes we can draw a conclusion not from premises known with certainty to an equally certain conclusion but from various convergent clues to a reasonable (or probable) conclusion. Juries do this all the time". (Kreeft \& Tacelli, 2009, p. 21) Thus, probabilistic statements can be considered as part of our knowledge (Moss, 2018, pp. 1-2). A distinction can be made between the results of probability theory and our belief in the results (Bartholomew, 1988; Ramsey, 1926). If we are not comfortable with mathematics, then mathematics and the logical background to the results of probability theory may not mean much (Adrien \& Dirac, 1963). However, it should still be an important question for us in terms of the data used in the calculations. For example, if I am interested in the likelihood of success of some medical treatment 
for my child, then the data on the same method for middle-age persons may not be decisive for my case but may provide some contributing knowledge.

There is a further issue in terms of interpretation, since the interface between causality and probability is not well established. There is no general consensus among philosophers as to what probabilistic information tells us, how objective that information is, and whether we can we apply it directly to our own, concrete situation (Childers, 2013).

In this paper, we use the word 'possibility' to indicate that a particular outcome is feasible, and the term 'uncertainty' to mean that the outcomes of a behavior or situation are not known in advance, and the probability of a particular outcome cannot be calculated. We use the term 'risk' (and the allied term 'probability' as discussed above) to mean situations where some calculation of the probability of harm may be made (Taylor, 2017b). However, we recognize that the use of estimates makes the distinction between these terms less useful in practice than in theory (Taylor, 2020a), and that everyday usage may differ more widely than among the scientific and philosophical community (Hansson, 2018).

We avoid use of the term 'chance' as current usage is not clearly enough defined for our purposes (Bartholomew, 2008; Bohm, 1971), particularly as for some it implies 'randomness' (Mahner \& Bunge, 1997) whereas the essence of our discussion is about patterns (non-randomness) within probabilistic knowledge (Boeri, 1995; Feynman, 1987). Also the term 'chance' may imply ethical and emotional connotations, irrelevant to this discussion, in relation to contexts such as gambling. We define terms related to the philosophy of Thomas Aquinas (including his use of the term 'chance') within the body of the paper, as part of the discussion below of the application of scholastic philosophy to risk science in social welfare.

In this regard, can human reflection and estimation, though deficient and conditioned, still be considered irreplaceable when social welfare workers are assessing the 'risks' (such as of child abuse occurring or not) in a particular situation? On the other hand, probabilistic information can offer better insight into the concrete situation and its development. Therefore, the question arises as to how to use probabilistic information about possible risks in social welfare, what are the advantages, what are the disadvantages, and how decisive such information can be in making concrete decisions concerning the lives of individuals and their families.

\section{Challenges of Risk Science in Social Welfare}

In the field of health and social care, it is common nowadays to say things such as 'smoking causes lung cancer'. By this it is not meant that every person who smokes gets lung cancer nor that everyone who has lung cancer has smoked (Price \& Djulbegovic, 2017). What is meant is that there is a sufficiently strong statistical correlation between the prevalence of smoking and lung cancer across a sufficiently large sample of people, and that there are widely-accepted theoretical and temporal reasons for concluding that it is smoking that is causative (i.e., influences the occurrence of) of lung cancer not lung cancer that is causing (influencing) people to smoke (Djulbegovic et al., 2009). Smoking is thus called a 'risk factor' for lung 
cancer, alongside other risk factors that have been identified and accepted by the appropriate scientific community using comparable standards (Molina et al., 2008). Despite reasonable clarity among epidemiologists, the statement 'smoking causes lung cancer' may still lead to misunderstanding among some of the general population (Parker \& Davies, 2020).

In the field of social welfare, there are similar examples of probabilistic statements about risk factors that indicate a higher probability of harm occurring. Examples include: parental mental illness or poverty as predictive (i.e., 'causative') of child neglect; parental separation as predictive of the children becoming involved in crime or drug addiction; drug abuse or being a prisoner as predictive of suicide; sexual abuse as a child as predictive of adult mental health problems; etc. (Taylor, 2012). As in health care, these statements are not meant to imply that there is an absolute deterministic causation but, rather, that the risk factor (causative factor) increases the probability of the consequence occurring in the population to some measurable and significant extent, and that there are theoretical and temporal reasons to draw conclusions on the direction of causation (Mc Elhinney et al., 2021). Probabilistic statements about social welfare harms are perhaps even more misunderstood than those relating to (probabilistic) 'causes' of illnesses (Garrow \& Yeheskel, 2017). This is perhaps because probability science is more recently applied in social welfare; perhaps because the ethical (and sometimes legal) implications may be wider; and perhaps because there is greater complexity to consider.

Social workers are employed in many countries of the world to help individuals and families to avoid and address behaviors and situations that lead to harmful and undesirable outcomes such as child abuse and neglect; mental health problems; crime; and accidents by older people and those with disabilities. With the rise of 'the risk society' (Beck, 1992), considerations of 'uncertainty' are becoming a more important part of the social work role. Increasing attention is being given to risk factors that are predictive (i.e., indicating a probabilistic causal relationship) that harm is more likely to occur in certain situations, so that action might be taken to address the issues and underlying 'causative' problems. This paper explores some philosophical issues inherent in such predictive modeling and preventive services-based on the probabilistic reasoning above - which add a new dimension to the traditional social work activity of helping individuals and families to address evident presenting needs (Duffy et al., 2006; Fengler, \& Taylor, 2019; Taylor, 2012).

As the number of social welfare risk factors studied through research grows, the task of identifying and weighing up such risks becomes more complex (McCafferty, \& Taylor, 2020; McGinn et al., 2016; Schrödter et al., 2020; Søbjerg et al., 2020). The development of 'big data' and machine learning promises (or threatens!) to increase the detail of our knowledge of such risk factors (Taylor, 2020b). This will make the challenges for social workers greater, and the issue more pressing in terms of the philosophical, ethical and legal issues involved (Grimwood, 2016; Taylor, \& Campbell, 2011). Some in the social work profession welcome these developments arguing that it is more accurate and more ethical than purely human judgments (which generally lack transparency of argument) (Johnson, 2011; Vaithianathan et al., 2013; Coulthard et al., 2020). Others fear or do not understand the use of probabilistic knowledge in what is essentially a human interaction process (Keddell, 
2011) and look toward more intuitive understandings of decision processes (Sicora et al., 2021). This paper explores some of the epistemological issues.

Social work is at a stage where the philosophical foundations of the profession require deeper reflection (Halvorsen, 2018). This includes reflection on the coherence-correspondence debate, that is, whether the essence of robust professional knowledge is that it is internally coherent or that it is an accurate representation of reality (Polonioli, 2015). This paper explores epistemological issues regarding the use by social workers of probabilistic knowledge regarding risks to social wellbeing, examined particularly from the perspective of scholastic philosophy.

From an epistemological perspective, a central issue is how to make sense of probabilities in a conceptual framework of causation, free will and responsibility for our actions (Gregersen, 2003, 2006). The worlds of philosophy and theology may seem disconnected with the (perhaps obsessive) conceptualization of 'risk' in modern society (Althaus, 2005). Risk factors (i.e., probabilistic knowledge about possible harms) might be conceptualized as causes within the created world (Verschuuren, 2016), although we may be more comfortable to assert, with Einstein, that 'God does not play dice' (Canetta, 2014). Following on this, according to philosopher Ian Hacking (1975) the research on probability and decision-making processes was strongly advanced after Blaise Pascal's Wager argument on God's (non)existence and how should rational persons live their life.

We turn to considering how the challenge of risk science in social welfare might be considered in terms of the philosophical conceptualization of Thomas Aquinas (1225-1274). Despite a period of neglect, scholastic philosophy is experiencing something of a revival, not least in relation to causality and modern science (Dodds, 2012; Wallace, 1997). Indeed, in his masterful summary of the 'angelic doctor', Anthony Kenny (Kenny, 1980) argues that aspects of Aquinas' work are not antiquated by scientific progress, and that his thought remains relevant to modern study in the philosophy of mind. Thomas Aquinas considered that our human understandings of truth proceed from senses (which underpin observation in the natural sciences) to imagination (which we might express today as mental visualization) to abstraction (which might be considered in terms of modern psychology as cognitive mapping). One challenge is whether we can describe probabilistic knowledge as 'rooted in the senses'. Are risk factor statistics comparable to, say, understanding Einstein's General Theory of Relativity during the years before we had empirical proof of this based on real-world observations (Dyson et al., 1920)? Is the imagination step useful when we are considering sense data for which we have a statistical probability that something may be true? And for the abstraction step in Aquinas' model, how does probabilistic knowledge contribute to an integrated cognitive 'knowledge' about something (Collier, 2012), in this case risk factors for social harm? A key task is to relate this discussion to Aquinas' understanding of causality and 'substantial form' (Albertson, 1954; Dodds, 2009; Nichols, 1996; Sokolowski, 1995). 


\section{Thomistic Understandings of Acquiring Knowledge and Probability}

As Bell (1979) once suggested, in order to understand the contribution of Thomas Aquinas to contemporary science, the current sociological categories must be transposed into categories familiar to Thomas Aquinas and not just simply search for modern terms in scholastic writings. Therefore, in case of uncertain or risky situations, it means referring to the principles indicated by prudence, one of the cardinal virtues, which conceptualizes how we regulate human actions in relation to nonobvious matters (continengentia) that are difficult to predict (Mróz, 2001). In such situations, no rigid pre-established rules can be applied such as as 'copy past activity'. What prudence can offer, however, it a concept of applying general laws (recta ratio agibilium) to specific situations in order to avoid harm. In this way, the recent renaissance of interest in Thomistic studies on prudence consists mainly in method of dealing with current social challenges based on Aquinas philosophical solution although in a different conceptual framework. Among examples of uses of Thomistic tools, we find Scherz's considerations on gene-drive technology, analyzed from the perspective of integral parts of prudence in terms of health benefits and ecological risk (Scherz, 2017). There are also applications of prudence to family life, decisions made by leaders (Kaak et al., 2013), directions of education (Love, 2019) and spiritual stability (Clairmont, 2013). These suggest that, in the case of risk factors for social harm also, there is value in engaging with Aquinas' ideas.

Before discussing the principles of prudent activity, it is worth characterizing the anthropological framework (Rozier, 2017) in which human activity is part of a probabilistic approach to reality and then to focus on the Thomistic criteria of appropriate response to what can be harmful, and what is guided by caution and other components of prudence. The avoidance of external and internal damage is precisely the main task of prudence.

\section{Anthropological Framework for Risk Science in a Thomistic Lens}

The whole metaphysical framework of Aquinas is related to actualizing the possibilities that are inherent in our human contingent being: to have a nature does not mean to act in only one concrete way. The main characteristic of human being is to be in fieri: we were created not as finished being, but open to self-actualization although with some nature understood as a stable principle of identity, as a kind of ars (Artigas, 2001; Edwards, 2017). For Aquinas self-possession through the deliberated decision is something good: if we had been created in final form, without possibility (and risk) of growing in perfection, we would lose a good of 'becoming good' which is not proper to God as Summum Bonum (Martinez, 2012).

For a human being to find him- or herself in a risk situation is normal, but requires an appropriate response to external factors (Zellma et al., 2021). The main criterion is to act according to our proper nature and to maintain an orientation toward the final goal. That is why we need virtue, habits that strengthen our free choosing of adequate means in accordance to the hierarchy of goods. Thanks to the virtue, we know not only the real good, but we are able to distinguish it from what is only 
apparent good, established relations or social welfare on the base of real situation. All this capacity is formed by the virtue of prudence that involves correct knowledge of reality and circumstances (Mróz, 2018). It requires experience and analytic-oriented conduct, aware at each stage of the possible deviation from the good, but also a capacity to receive a counsel. Richard Cross (1994) summarizes Aquinas' characteristics of prudence in contingence situations:

"Prudence is not about an understanding of the ends, or about what is right or wrong, but of the ability to put into effect the means that secure a good end. Prudence is also understood to be associated with counsel, which is the ability to help someone else by way of placing before them information of due consideration of both the natural law and the contingent circumstances. What is quite clear from these ancient teachings is that in order to be prudent and to give good counsel you have to have had experience. Experience means, among other things, learning from mistakes, yours as well as others. Of course, one cannot ascertain that some particular action is good or bad unless they bring to bear some standard. The use of standards involves judging, and also being able to weigh in the nature of contingency, or circumstance." (p. 109)

Being rational, human beings treat what is harmful differently from animals. We react not only with a certain natural instinct (aestimatio), but also through deliberatio rationis, i.e., through the effort of reason (Super Sent., lib. 2 d. 20 q. 2 a. 2 ad 5. See also: In Sent., lib. 2, d. 24, q. 3, a. 1 c.). In the face of harmful evil, some specific feelings arise (timor, tristitia and ira), which must be subjected to reason (Super Sent., lib. 3 d. 33 q. 3 a. 3 qc. 1 ad 3.). Harmful situations are described in the language of Aquinas as nocumentum (Super Sent., lib. 2 d. 35 q. 1 a. 1 ad 3. $\mathrm{T})$, where the term mainly concerns moral life and the influence of harmful speech (nocumentum oris), heart or feelings, internal convictions (nocumentum cordis), resulting from sin (ex pecato; Summa Theologiae I-II, q. 73 a. 8c) or the action of one person that harms another (alteri, proximum). Thus, Aquinas analyzes the types of damage, establishing a specific hierarchy of damage. But he also wonders how to react to deeds that can harm others, and he proposed the correctio as an appropriate way.

It is worth noting that Aquinas' attitude toward risk is not simply about one solution or method, but about considering the situation from multiple points of view. For example, his Quodlibetal Questions considers many everyday situations (e.g., who should be chosen as a leader, good or capable person?), demonstrating his efforts to apply general laws to specific cases. Aquinas' recipe is not to develop one set of skills, but to comprehend human beings as a whole. In consequence, some virtues guide the others. There is a nexus virtutum, connection of all virtue. The goal consists not in transmission of techniques, but to form a prudent man; it is not only about epistemic risk, but about persistent realization of good according to practical reason. Therefore, Aquinas notes in reflection on the virtue of prudence that "although in certain other intellectual virtues reason is more certain than in prudence, yet prudence above all requires that man be an apt reasoner, so that he may rightly apply universals to particulars, which latter are various and uncertain. (Summa Theologiae II-II, q. 49, a.5, ad 2.)" This often means seeing many different possibilities of 
human action. That is why, thanks to prudence, we gain a knowledge of the good not only intellectually but also affectively (Huzarek, 2015; Tabossi, 2016). In the case of social welfare, it means the ability to empathize with situations, to understand affectively the situations of other people.

All these properties capture integral parts of prudence (i.e., those elements that are necessary for prudence to be as such), and he mentions: memory, understanding, docility, shrewdness, reason, foresight, circumspection and caution. These all help in making decisions about right action in a situation of uncertain cognition (cognitio incerta).

First, memory as understood here by Aquinas, it is not just a memory technique, but the ability to remember past events and use this material. It does not consist simply in collecting impressions, but organizing them intellectually, so sometimes an excess of stimuli can be harmful, and for this reason, a special skill is needed.

What Aquinas called understanding means being aware of what is present, what is individual, such a "sense of reality", a clear view of situations. It is the correct and proper perception of the final rule which is self-evident. Prudence, therefore, comes from universal principles, e.g., that "no one should be hurt", and from the perception of a particular goal on which the person wants to act. The accurate assessment of the goal is the awareness that helps us to see order in complex processes, and to eliminate erroneous ideas and concepts, so as not to distort the perception of the world with fantasies.

In order to benefit from other people's experiences, the virtue of docility is required. But it is also ingenuity in finding sources of knowledge, undertaking hardships, and perseverance. Shrewdness is forethought, insight, and accuracy in estimating when we lack full knowledge. This ingenuity is valuable when you need to find a solution quickly! Besides, an aspect of prudence is drawing conclusions from the collected material, i.e., particular applications of common principles to the concrete situation-what is called as reason. But to do this as a human being needs also foresight (anticipating possible future events) and circumspection (assessing circumstances), chosen by providence but now evaluated as to how much they help to achieve the goal. Ultimately, caution is required to distinguish between evil creeping into good.

\section{Aquinas on Caution as Part of Prudence}

The caution mentioned as a quasi "integral part of prudence", is the principle of avoiding harmful situations in the achievement of certain goods. Aquinas does not mean that we should be suspicious at all times; on the contrary, he recommends trusting as a general rule. However, if there is a risk of harming another person then he recommends that we should be epistemically open and be careful, as:

"the things with which prudence is concerned, are contingent matters of action, wherein, even as false is found with true, so is evil mingled with good, on account of the great variety of these matters of action, wherein good is often hindered by evil, and evil has the appearance of good. Wherefore pru- 
dence needs caution, so that we may have such a grasp of good as to avoid evil." (Summa Theologiae II-II, q.49, a.8c.)

This quotation highlights the need in Aquinas' thinking of taking into account not only relevant constant factors, but also potentially-relevant variables that are not predictable in advance (Conrad \& Hunter, 2020). Then the criteria set by recta ratio turn out to be crucial. So, it is about the ability to understand deeply the reality that has traditionally been identified as wisdom. However, we should distinguish wisdom as risk-taking and as understanding in light of ultimate causes (Yang, 2017). Aquinas describes this in following words:

"Of the evils which man has to avoid, some are of frequent occurrence; the like can be grasped by reason, and against them caution is directed, either that they may be avoided altogether, or that they may do less harm. Others there are that occur rarely and by chance, and these, since they are infinite in number, cannot be grasped by reason, nor is man able to take precautions against them, although by exercising prudence he is able to prepare against all the surprises of chance, so as to suffer less harm thereby." (Summa Theologiae II ${ }^{\text {a }}$-IIae q. 49 a. 8 ad 3)

Thus, caution facilitates seeing good and, by focusing attention on good, a person gains the ability to see evil creeping in the good, distinguish it and replace it.

In summary, in the face of risky situations and the possibility of harm, Aquinas seems to suggest the following criteria: (1) choose the greater good than the lesser evil; (2) analyze different points of view; (3) anticipate possibly harmful situations using imagination; and (4) use integrity and awareness of the situation.

\section{Conclusions}

Probabilistic statements about risk factors are used in many aspects of modern life. However, there is justifiable concern when it comes to social welfare, perhaps because there are issues of rationality and free will of the individual which are not so determined as in relation to the human body where biological and genetic laws pertain.

Preventive reasoning in social welfare needs to make decisions by proposing different hypotheses (A, B or C) of outcomes in a particular case. Looking at the evidence of the case, social workers need to evaluate which hypothesis relating to a particular outcome is confirmed, supported or decisive, or to put in another way, "how probable these hypotheses are in light of the evidence" (Eagle, 2016, p. 428). Aquinas' philosophy offers helpful insight into the decision-making process with a specific goal (choose the greater good than the lesser evil), and in the assessment of all circumstances or evidence in a particular case, and the adoption of preventive measures against possible harm.

Subjective probability existed in human behavior long before probability theory as such was developed. The example of the philosophy of Thomas Aquinas helpfully outlines this and helps us to frame the epistemological perspective. Therefore, we 
could say that probabilistic knowledge is part of the process of shaping our understanding and wisdom in making risk assessments in specific situations.

Emphasizing a few essential points from Aquinas' philosophy of prudence defined as "the ability to put into effect the means that secure a good end", probability theory is recognized as an inherent and useful tool available to the individual. Contemporary use of the term "big data" can be translated into Aquinas' emphasis on communication and consultation with those who have experience and who have learned from mistakes. In judging these experiences, Aquinas emphasizes the use of standards or principles. Big data can be understood as a large amount of "accumulated human experience", classified using mathematical and logical principles. Of course, these principles, as well as the background of the "experience" being processed, must be transparent if they are to be part of the social worker's decisionmaking process.

In this way, social workers have two types of data and/or knowledge sources at their disposal: on the one hand, their own subjective experience, as well as the experience of colleagues, and on the other hand, mathematical analyzes of big data that provide a certain mathematical objectivity of reality. Just as one's own and others' experiences necessarily need critical reflection in order to identify the essential facts of individual cases at hand, so understanding the perspectives and boundaries of big data plays an essential role. In this paper, the emphasis is placed on human (self) reflection guided by Thomistic principles, which can also be applied in the synthesis of the above two sources of data and/or knowledge.

In a situation of uncertain cognition, the challenge is how to make decisions about right action. Aquinas emphasizes the need to understand the whole of the human being, looking at the concrete situation from various perspectives in order to realize the right measures of action, having good as the overarching purpose. Using all properties of prudence (memory, understanding, docility, shrewdness, reason, foresight, circumspection and caution), the individual better understands the specific situation. Probabilistic knowledge can certainly help him or her in this, especially in terms of memory (more data-bigger artificial memory), docility (to be able to know how to learn from statistical data) and foresight (to have some information, beyond personal experience and inclinations, about possible the future events). However, the property of caution can and should protect against uncritical evaluation of probabilistic results. An important role is also played by understanding, which removes misconceptions and protects the perception of the world from the illusions that an uncritical approach to probabilistic knowledge could yield.

This paper has explored the application of the conceptualizations of Thomas Aquinas may be applied to risk issues in understanding contemporary social wellbeing and social work services. The concepts of scholastic philosophy might be applied also to other aspects of modern health and social welfare so as to clarify the epistemological underpinnings and thereby support rational debate to improve public and charitable services.

It is interesting how Aquinas places emphasis on empathy for the situation of the individual, which is also an important component in assessing the situation for social workers, and which probabilistic knowledge cannot set as a category or variable at all. 
Perhaps the most important thing that we can learn from Aquinas on this topic is his respect for counsel or consulting with others on a specific situation. Statistical knowledge and communication with colleagues make a contribution, but through reflection on basic epistemology a more profound understanding of the complexity of situations and risks can be achieved. For Aquinas, this is wisdom.

Acknowledgements We would like to thank our many colleagues and students in philosophy, theology and social work who have enriched us, often informally, with their ideas.

Author Contributions All three authors made an identifiable contribution to the manuscript, particularly in relation to philosophy, theology and social welfare, respectively.

Funding There was no funding for this paper.

Availability of Data and Materials There is no empirical data for this paper.

Code Availability Not applicable.

\section{Declarations}

Conflict of interest There are no conflict of interest to declare.

\section{References}

Adrien, P., \& Dirac, M. (1963). The physicist's picture of nature. Scientific American, 208, 45-53. https:// doi.org/10.1038/scientificamerican0563-45

Albertson, J. S. (1954). Instrumental causality in St Thomas. New Scholasticism, 28(4), 409-435. https:// doi.org/10.5840/newscholas195428455

Althaus, C. E. (2005). A disciplinary perspective on the epistemological status of risk. Risk Analysis, 25, 567-588. https://doi.org/10.1111/j.1539-6924.2005.00625.x

Artigas, M. (2001). The mind of universe. Templeton Foundation Press.

Bartholomew, D. J. (1988). Probability, statistics and theology (with discussion). Journal of the Royal Statistical Series a: Society Statistics in Society, 151, 137-159. https://doi.org/10.2307/2982190

Bartholomew, D. J. (2008). God, chance and purpose: Can God have it both ways? Cambridge University Press.

Beck, U. (1992). Risk society: Towards a new modernity. Sage.

Bell, D. (1979). The cultural contradictions of capitalism (2nd ed.). Heinemann Educational.

Boeri, M. D. (1995). Chance and teleology in Aristotle's physics. International Philosophical Quarterly, 35, 87-96.

Bohm, D. (1971). Causality and chance in modern physics. University of Philadelphia Press.

Canetta, E. (2014). Physics and beyond: "God does not play dice"; What did Einstein mean?. Physics Café Series, St Mary's University Twickenham. https://www.stmarys.ac.uk/news/2014/09/physicsbeyond-god-play-dice-einstein-mean

Childers, T. (2013). Philosophy and probability. Oxford University Press.

Clairmont, D. (2013). Medieval consideration and moral pace: Thomas Aquinas and Bernard of Clairvaux on the temporal aspects of virtue. Journal of Religious Ethics, 41(1), 79-111.

Collier, P. (2012). A most incomprehensible thing: Notes towards a gentle introduction to the mathematics of relativity (3rd ed.). Incomprehensible Books.

Conrad, R., \& Hunter, P. (2020). Why Aquinas would agree that human economic behaviour is largely predictable'. In P. Róna \& L. Zsolnai (Eds.), Agency and causal explanation in economics (pp. 93-113). Springer. https://doi.org/10.1007/978-3-030-26114-6 
Coulthard, B., Mallett, J., \& Taylor, B. J. (2020). Better decisions for children with 'big data': Can algorithms promote fairness, transparency and parental engagement? Societies, 10, 97. https://doi.org/ $10.3390 /$ soc 10040097

Cross, R. (1994). Can Catholics counsel? The loss of prudence in modern humanist psychology. Faith \& Reason, 20, 87-111.

Daston, L. (1994). How probabilities came to be objective and subjective. Historia Mathematica, 21(3), 330-344. https://doi.org/10.1006/hmat.1994.1028

de Finetti, B. (1975/2017). Theory of probability: A critical introductory treatment. Wiley.

Djulbegovic, B., Guyatt, G. H., \& Ashcroft, R. E. (2009). Epistemological inquiries in evidence-based medicine. Cancer Control, 16(2), 158-168. https://doi.org/10.1177/107327480901600208

Dodds, M. J. (2009). Unlocking divine causality: Aquinas, contemporary science and divine action. Angelicum, 86(1), 67-86.

Dodds, M. J. (2012). Unlocking divine action: Contemporary science and Thomas Aquinas. Catholic University of America Press.

Duffy, J., Taylor, B. J., \& McCall, S. (2006). Human rights and decision making in child protection through explicit argumentation. Child Care in Practice, 12, 81-95. https://doi.org/10.1080/13575 270600618331

Dyson, F. W., Eddington, A. S., \& Davidson, C. (1920). A determination of the deflection of light by the Sun's gravitational field, from observations made at the total eclipse of 29 May 1919. Philosophical Transactions of the Royal Society, 220A, 291-333. https://doi.org/10.1098/rsta.1920.0009

Eagle, A. (2016). Probability. In P. Humphreys (Ed.), The Oxford handbook of philosophy of science (pp. 417-440). Oxford University Press.

Edwards, D. (2017). The natural world and God: Theological explorations. ATF Theology.

Fengler, J., \& Taylor, B. J. (2019). Effective assessment: a key knowledge and skill for a sustainable profession. Social Work Education: the International Journal, 38, 392-405. https://doi.org/10.1080/ 02615479.2018.1538333

Feynman, R. P. (1987). The character of physical law. MIT Press.

Garrow, E. E., \& Yeheskel, H. (2017). The epistemological challenges of social work intervention research. Research on Social Work Practice, 27, 494-502. https://doi.org/10.1177/1049731515 623649

Gigerenzer, G., Swijtink, Z., Porter, T., Daston, L., Beatty, J., \& Kruger, L. (1989). The empire of chance: how probability changed science and everyday life (ideas in context). Cambridge University Press. https://doi.org/10.1017/CBO9780511720482

Gregersen, N. H. (2003). Risk and religion: Towards a theology of risk. Zygon, 38(2), 355-376. https:// doi.org/10.1111/1467-9744.00504

Gregersen, N. H. (2006). Beyond secularist supersessionism: Risk, religion and technology. Ecotheology, 11(2), 137-158. https://doi.org/10.1558/ecot.2006.11.2.137

Grimwood, T. (2016). Key debates in social work and philosophy. Routledge.

Hacking, I. (1975). The emergence of probability. Cambridge University Press.

Halvorsen, T. (2018). Philosophy of social work - a new and advantageous field of training and research. Journal of Social Work Practice, 33(1), 55-66. https://doi.org/10.1080/02650533.2018.1438994

Hansson, S. O. (2018). Risk. In E. N. Zalta (Ed.), The Stanford encyclopedia of philosophy. https://plato. stanford.edu/archives/fall2018/entries/risk/

Huzarek, T. (2015). Experimental cognition of God in the commentary on the gospel of St. John according to Thomas Aquinas. Jahrbuch Für Religionsphilosophie, 14, 238-256.

Johnson, W. L. (2011). The validity and utility of the California Family Risk Assessment under practice conditions in the field: A prospective study. Child Abuse and Neglect, 35(1), 18-28. https://doi.org/ 10.1016/j.chiabu.2010.08.002

Kaak, P., Lemaster, G., \& Muthiah, R. A. (2013). Integrative decision-making for Christian leaders: Prudence, organizational theory, and discernment practices. Journal of Religious Leadership, 12(2), 145-166.

Keddell, E. (2011). Reasoning processes in child protection decision making: Negotiating moral minefields and risky relationships. British Journal of Social Work, 41(7), 1251-1270.

Kenny, A. (1980). Aquinas. Oxford University Press.

Kreeft, P. J., \& Tacelli, R. K. (2009). Handbook of Catholic apologetics. Ignatius.

Love, J. D. (2019). Aquinas's "Integral Parts of Prudence" as a resource for human formation. New Blackfriars, 1090, 698-714. https://doi.org/10.1111/nbfr.12504

Mahner, M., \& Bunge, M. (1997). Foundations of biophilosophy. Springer. 
Martinez, E. (2012). Bonum amatur inquantum est communicabile amanti. Amor y bien en la metafísica de Santo Tomás de Aquino. Espíritu, 61, 73-92.

Mc Elhinney, H., Taylor, B. J., \& Sinclair, M. (2021). Judgements of health and social care professionals on a child protection referral of an unborn baby: Factorial survey. Child Abuse and Neglect. https:// doi.org/10.1002/car.2661

McCafferty, P., \& Taylor, B. J. (2020). Barriers to knowledge acquisition and utilisation in child welfare decisions: A qualitative study. Journal of Social Work. https://doi.org/10.1177/1468017320978917

McGinn, A. H., Taylor, B. J., McColgan, M., \& McQuilkin, J. (2016). Social work literature searching: current issues with databases and online search engines. Research on Social Work Practice, 26, 266-277. https://doi.org/10.1177/1049731514549423

Molina, J. R., Yang, P., Cassivi, S. D., Schild, S. E., \& Adjei, A. A. (2008). Non-small cell lung cancer: Epidemiology, risk factors, treatment and survivorship. Mayo Clinic Proceedings, 83(5), 584-594. https://doi.org/10.4065/83.5.584

Moss, S. (2018). Probabilistic knowledge. Oxford University Press.

Mróz, M. (2001). Człowiek $w$ dynamizmie cnoty. Aktualność aretologii św. Tomasz z Akwinu w świetle pytania o podstawy moralności chrześcijańskiej. WSD.

Mróz, M. (2018). Physiological and psychological foundation of virtues: Thomas Aquinas and modern challenges of neurobiology. Scientia et Fides, 6(2), 115-128. https://doi.org/10.12775/SetF.2018. 019

Nichols, T. (1996). Aquinas' concept of substantial form and modern science. International Philosophical Quarterly, 36(3), 303-318. https://doi.org/10.5840/ipq199636317

Parker, J., \& Davies, B. (2020). No blame no gain? From a no blame culture to a responsibility culture in medicine. Journal of Applied Philosophy, 37(4), 646-660. https://doi.org/10.1111/japp.12433

Polonioli, A. (2015). The uses and abuses of the coherence-Correspondence distinction. Frontiers in Psychology, 6, 507. https://doi.org/10.3389/fpsyg.2015.00507

Price, A., \& Djulbegovic, B. (2017). What does evidence mean? Most languages translate "evidence" into "proof." Journal of Evaluation in Clinical Practice, 23(5), 971-973. https://doi.org/10.1111/ jep. 12834

Ramsey, F. P. (1926). Truth and probability. In F. P. Ramsey (Ed.), The foundations of mathematics and other logical essays (pp. 156-198). Humanities Press.

Rosenberg, A., \& McIntyre, L. (2020). Philosophy of science. Routledge.

Rozier, M. (2017). Religion and public health: Moral tradition as both problem and solution. Journal of Religion and Health, 56, 1052-1063. https://doi.org/10.1007/s10943-017-0357-5

Savage, L. J. (1954). The foundations of statistics. Wiley.

Scherz, P. (2017). Prudence, precaution, and uncertainty: Assessing the health benefits and ecological risks of gene drive technology using the quasi-integral parts of prudence. The Thomist, 81(4), 507537. https://doi.org/10.1353/tho.2017.0039

Schrödter, M., Bastian, P., \& Taylor, B. J. (2020). Risikodiagnostik und Big Data Analytics in der Sozialen Arbeit [Risk diagnostics and big data analytics in social work]. In N. Kutscher, T. Ley, U. Seelmeyer, F. Siller, A. Tillmann, \& I. Zorn (Eds.), Handbuch Soziale Arbeit und Digitalisierung [Handbook of social work and digitalisation], Ch 19 (pp. 255-264). Beltz Juventa.

Sicora, A., Taylor, B. J., Alfandari, R., Enosh, G., Helm, D., Killick, C., Lyons, O., Mullineux, J., Przeperski, J., Rölver, M., \& Whittaker, K. (2021). Using intuition in social work decision making. European Journal of Social Work. https://doi.org/10.1080/13691457.2021.1918066

Søbjerg, L. M., Taylor, B. J., Przeperski, J., Horvat, S., Nouman, H., \& Harvey, D. (2020). Using riskfactor statistics in decision making: prospects and challenges. European Journal of Social Work. https://doi.org/10.1080/13691457.2020.1772728

Sokolowski, R. (1995). Formal and material causality in science. Proceedings of the American Catholic Philosophical Association, 69, 57-67.

Tabossi, G. (2016). El conocimiento del bien por connaturalidad afectiva: El dinamismo integral de la prudencia en la IIa-IIæ de la Suma Teológica de santo Tomás de Aquino. Revista Teología, 120, $101-120$.

Taylor, B. J. (2012). Models for professional judgement in social work. European Journal of Social Work, 15, 546-562. https://doi.org/10.1080/13691457.2012.702310

Taylor, B. J. (2017a). Heuristics in professional judgement: a psycho-social rationality model. British Journal of Social Work, 47, 1043-1060. https://doi.org/10.1093/bjsw/bcw084

Taylor, B. J. (2017b). Decision making, assessment and risk in social work (3rd ed.). Sage. 
Taylor, B. J. (2020a). Risk-managing decision making: a psycho-social rationality model. British Journal of Social Work. https://doi.org/10.1093/bjsw/bcaa094

Taylor, B. J. (2020b). Teaching and learning decision making in child welfare and protection social work. In J. Fluke, L. M. López, R. Benbenishty, E. J. Knorth, \& D. Baumann (Eds.), Decision making and judgement in child welfare and protection: Theory, research and practice, Ch 13 (pp. 281-300). Oxford University Press.

Taylor, B. J., \& Campbell, B. (2011). Quality, risk and governance: Social Workers' perspectives. International Journal of Public Leadership, 7, 256-272. https://doi.org/10.1108/17479881111194152

Vaithianathan, R., Maloney, T., Putnam-Hornstein, E., \& Jiang, N. (2013). Children in the public benefit system at risk of maltreatment: Identification via predictive modeling. American Journal of Preventive Medicine, 45(3), 354-359. https://doi.org/10.1016/j.amepre.2013.04.022

Verschuuren, G. V. (2016). Aquinas and modern science: A new synthesis of faith and reason. Angelico Press.

Waite, L. J. (2018). Social well-being and health in the older population: moving beyond social relationships. In M. K. Majmundar \& M. D. Hayward (Eds.), Future directions for the demography of aging: Proceedings of a workshop (pp. 99-131). The National Academies Press. https://doi.org/10. $17226 / 25064$

Wallace, W. A. (1997). Thomism and the quantum enigma. The Thomist, 61, 455-467. https://doi.org/10. 1353/tho.1997.0022

World Health Organization. (1948). Constitution of the World Health Organization. www.who.int/gover nance/eb/who_constitution_en.pdf

Yang, E. (2017). Wisdom, risk-taking, and understanding. Philosophy \& Theology, 29(2), 419-428. https://doi.org/10.5840/philtheol201782487

Zellma, A., Buchta, R., \& Cichosz, W. (2021). The (non)transgressive character of religious education for children and young people in Polish schools. British Journal of Religious Education. https://doi.org/ $10.1080 / 01416200.2021 .1887082$

Publisher's Note Springer Nature remains neutral with regard to jurisdictional claims in published maps and institutional affiliations. 